\title{
Why Pre-Electoral Coalitions in Presidential Systems?
}

\author{
MARISA KELLAM*
}

\begin{abstract}
Why do political parties join coalitions to support other parties' presidential candidates if presidents, once elected, are not bound to their pre-electoral pledges? This article argues that policy agreements made publicly between coalition partners during the campaign help parties pursue policy goals. However, parties cannot use pre-electoral coalitions to secure access to patronage, pork and government benefits under the control of presidents because they cannot hold presidents accountable to these agreements. Quantitative analysis of Latin American electoral coalitions demonstrates that political parties are more likely to form presidential electoral coalitions as the ideological distance between them decreases. Yet presidential electoral coalitions tend not to include non-programmatic political parties, even though such office-oriented parties are unconstrained by ideological considerations.
\end{abstract}

In their search for winning majorities, or at least winning pluralities, it is common for multiple political parties to support a single presidential candidate. In the first round of the Brazilian presidential election in 2010, Dilma Rousseff's electoral coalition Para o Brasil Seguir Mudando included nine parties other than her own Partido dos Trabalhadores. The electoral victory of president Sebastián Piñera of Chile in 2010 also came about through an electoral coalition - the Coalición por el Cambio - between his own Renovación Nacional, the Unión Demócrata Independiente and several other small parties. In the previous election, these two parties had competed against one another, splitting the right-wing votes and losing to the Concertación coalition.

As these examples illustrate, political parties that contest presidential elections with a candidate of their own may have an obvious electoral incentive to gain the endorsement of leaders from other political parties who can encourage their supporters to vote for the coalition candidate. But while the political party of the presidential candidate can form an alliance with multiple parties, each political party can formally support only one candidate (or none at all). Why do parties join pre-electoral coalitions to support other parties' presidential candidates? Presidential candidates may promise other parties that they will share spoils, distribute cabinet portfolios and make policy concessions should they win office, but previous research on multiparty presidentialism claims that presidential electoral coalitions 'are not binding past election day' and emphasizes how presidential electoral coalitions can differ from presidential governing coalitions. ${ }^{1}$ Scholars focus on the 'winner-take-all' aspect of presidential elections, ${ }^{2}$ the lack of interbranch and intraparty accountability in presidential systems, ${ }^{3}$

\footnotetext{
* Associate Professor, Waseda University (e-mail: kellam@aoni.waseda.jp). I thank Sona Golder, Royce Carroll, Michael Wahman, Kim Yi Dionne, Francisco Pedraza, Jana Morgan, Guy Whitten and Kaare Strøm for their comments on earlier versions of this article, and Rhonda Struminger for her research assistance. Data replication materials are available at https://dataverse.harvard.edu/dataverse/BJPolS, and online appendices are available at http://dx.doi.org/doi:10.1017/S0007123415000198.

1 Mainwaring and Shugart 1997, 397.

2 Linz 1994.

3 Samuels and Shugart 2010.
} 
and foresee governability problems if electoral coalitions do not translate into stable governing coalitions. $^{4}$

This contrasts with the theoretical explanation for majority parties and with the usual assumption in the parliamentary literature that pre-electoral coalitions are credible commitments to govern together after the election. Scholars argue that proto-coalitions of interest groups form 'long coalitions', otherwise known as majority parties, because members win more than they would otherwise by reducing uncertainty in the outcomes of repeated policy making and repeated electoral contests. ${ }^{5}$ Where constitutions stipulate electoral rules that encourage competition among multiple small parties, some parties form multiparty coalitions before elections, while others compete separately and form multiparty governing coalitions only after elections. Coalitions sometimes lead to party mergers but, as coalitions, they indicate that parties retain their separate identities and organizations. Pre-electoral coalitions (also called alliances or pacts) usually involve candidate nomination agreements made among parties before the election to govern together afterwards if they are electorally successful. Pre-electoral coalitions pre-empt voters' strategic calculations in multiparty contests and increase the probability of winning the election when rules favor larger parties; they also potentially influence the government that forms after the election, and thus policy outcomes. ${ }^{6}$

The explanation for presidential pre-electoral coalitions given in this article does not assume that parties will be able to hold post-electoral governments to their pre-electoral agreements. I argue that the act of forming a pre-electoral agreement itself can help political parties pursue some of their goals. Parties can use pre-electoral policy agreements made publicly on the campaign trail to identify and help elect the presidential candidates who are most likely to pursue policies that they favor, even though presidents are ultimately not bound to their campaign platforms. Yet parties cannot use pre-electoral coalitions in support of other parties' candidates as an office-seeking strategy - for example, to guarantee a place in the cabinet should their candidate win or to secure access to patronage, pork appropriations, and other government spoils that would be under the control of the winning presidential candidate and his or her cabinet ministers. These types of 'cheap talk' pre-electoral agreements are usually made behind closed doors, and parties cannot reliably punish presidents who fail to honor such commitments.

If policy goals motivate a party to support another party's presidential candidate, but officeseeking incentives do not, then we should expect pre-electoral coalition behavior to differ according to parties' goals. Policy-seeking parties should be more likely to support a presidential candidate from another party as the ideological distance between them decreases. But in many countries of Africa, Asia and Latin America, some parties are devoid of any coherent programmatic orientation. Instead of advancing policy platforms and ideological reputations, non-programmatic parties cultivate reputations solely as providers of particularistic benefits. To maintain this reputation, they seek access to selective office benefits under the control of presidents, which they obtain only if they get into presidents' post-electoral coalitions. Eager for cabinet posts and other office benefits, particularistic parties put their votes up 'for hire' in post-electoral presidential coalition bargaining. ${ }^{7}$ We should expect exclusively office-seeking parties to wait until after the election to engage in these kinds of coalition negotiations, unless the pre-electoral coalition involves a candidate nominated from their own party.

${ }^{4}$ Colomer and Negretto 2005; Conaghan 1995; Mainwaring 1993; Mainwaring and Shugart 1997; Payne et al. 2007.

${ }_{5}^{5}$ Aldrich 1995; Bawn and Rosenbluth 2006; Cox and McCubbins 1993; Schwartz 1989.

${ }^{6}$ Blais and Indridason 2007; Carey and Siavelis 2005; Carroll and Cox 2007; Debus 2009; Golder 2006b; Martin and Stevenson 2001.

${ }^{7}$ Kellam 2015. 
Empirical analysis of electoral coalition data from eleven Latin American countries demonstrates that presidential pre-electoral coalitions are common, and provides evidence in line with my theoretical argument for why parties join pre-electoral coalitions in support of another party's candidate. Drawing on data from seventy-seven elections, I find that a preelectoral coalition supported - in the first (or only) round - 37 per cent of the presidential candidates who won more than 10 per cent of the vote and 45 per cent of the candidates who ultimately served as president. I estimate a model of pre-electoral coalition formation among party dyads and find support for the hypothesis that programmatic, policy-seeking parties are more likely than particularistic, office-seeking parties to form electoral coalitions in support of another party's candidate. The results also indicate that for policy-oriented parties, the probability of electoral co-operation depends on the ideological distance between presidential parties and potential coalition partners.

\section{THE PUZZLE OF PRESIDENTIAL PRE-ELECTORAL COALITIONS}

Previous research on electoral coalitions in presidential systems mostly focuses on the electoral incentives and - more often than not - disincentives for coalition formation in presidential contests. Presidential elections are inherently disproportional, and since many presidential systems have multiple political parties, one might expect that presidential pre-electoral coalitions are common. Plurality electoral rules encourage electoral coordination through pre-electoral coalitions in presidential elections. ${ }^{8}$ However, many countries use majority run-off systems to elect presidents, and scholars typically argue that these systems discourage the formation of electoral coalitions in the first round and create only the illusion of a majority coalition in the second round. ${ }^{9}$ Potential contamination effects on concurrent legislative elections may also discourage pre-electoral coordination in the presidential contest. ${ }^{10}$

Scholars often argue that small parties independently enter the presidential race to influence post-election bargaining, and not because they expect to win. ${ }^{11}$ The supporters of such small parties presumably understand this strategy, and therefore do not strategically defect to a candidate who has a viable chance of winning. A risk for these voters is that their second- (or third-) most favorable candidate may not secure a spot in the second round if support is split across several ideologically similar parties or if the opposition co-ordinates on a single candidate who wins outright. For instance, Peruvian voters in the 2011 presidential run-off faced a choice between two candidates that Peruvian politician and Nobel Prize laureate Mario Vargas Llosa infamously compared to the choice between AIDS and cancer.

André Blais and Indridi Indridason demonstrate that, under some conditions, parties have an incentive to coalesce prior to the first round. ${ }^{12}$ Compared to when parties each run separate candidates, a first-round agreement may make it more likely that a candidate favorable to their bloc crosses the threshold required to avoid a second round, or at least secures a place in the second-round competition. A first-round agreement may also affect the success of a secondround agreement: even if one of the candidates of a potential coalition is likely to get into the second round without the support of other parties, it may be the case that competing, rather than co-operating, in the first round reduces voters' willingness to turn out and support the candidate of

8 Spoon and West 2015.

9 Jones 1994, 1999; Mainwaring and Shugart 1997; Perez-Linan 2006; Shugart and Carey 1992.

10 Amorim Neto and Cox 1997; Conaghan 1995; Ferrara and Herron 2005; Golder 2006a; Hicken and Stoll 2011; Samuels 2002; Shugart and Carey 1992.

11 Colomer and Negretto 2005; Samuels 2002; Shugart and Carey 1992; West and Spoon 2013.

12 Blais and Indridason 2007. 
another party in the second round (and such co-ordination may be necessary for victory). There are also some circumstances, such as with vote and free media pooling, when formalized electoral co-ordination benefits both the presidential party and its coalition partners in the legislature. ${ }^{13}$

Unlike some parliamentary pre-electoral coalitions in which the parties present separate electoral lists and simply announce that they plan to govern together if given the opportunity, presidential pre-electoral coalitions always involve a nomination agreement. Sona Golder describes distributional issues as being particularly 'stark' in presidential pre-electoral coalition negotiations: 'It is interesting to note that it is precisely where the electoral incentives to form a coalition are highest (presidential elections) that the distributional issues that need to be overcome are the most problematic. ${ }^{14}$ Conflicts over candidate nominations may be particularly pronounced among potential presidential parties that opinion polls or past electoral performance have shown to have relatively equal-sized support in the electorate. Major presidential candidates and/or presidential parties may be willing to run separately, rather than form a coalition with an ideologically neighboring party, and lose to the opposition in order to guarantee their survival as influential political actors. ${ }^{15}$ Golder argues that presidential term limits could increase the divisibility of the presidential office over time by making a party's promise to step aside in favor of their coalition partner's candidate in the next election more credible. ${ }^{16}$

Presidential pre-electoral coalitions could potentially be even more divisible if they involved the vice presidential (VP) nomination, the distribution of cabinet ministries, or other positions in the executive branch and state-owned enterprises. A common assumption is that presidential candidates offer office benefits or other resource commitments or agree to policy compromises in order to make joining their coalition beneficial to other parties. Josep Colomer and Gabriel Negretto argue that minor parties may gain more when they form coalitions before voting occurs if they can 'blackmail' major candidates by threatening to run independently, and thus can 'expect larger shares of candidates in congressional lists, offices, programme concessions or other compensation and spoils, even beyond the proportions of their likely voting support' ${ }^{17}$

Pre-electoral coalitions in presidential systems may imply shared control of government, including office benefits or policy influence, should the coalition win the election, but presidents are not required to honor any pre-electoral agreement. Given the separation of powers in a presidential system, presidents are not responsible to their coalition partners, or even their own party, in the legislature. ${ }^{18}$ Re-election incentives may constrain presidents, but they will not lose power if they fail to maintain a majority coalition. Since presidents have policy goals, minority presidents are likely to form multiparty governing coalitions with parties positioned in ideologically proximity. ${ }^{19}$ But post-electoral governing coalitions can include parties that were not part of the coalition that elected the president to office. As David Samuels and Matthew Shugart argue, presidents select their cabinets and pursue policy at their own discretion 'because after the election, the party that nominated the presidential candidate can no longer hold that person immediately accountable'. ${ }^{20}$ The nature of interbranch and intraparty politics in presidential systems means that pre-electoral coalitions are neither sufficient nor necessary for co-operation in government.

13 Machado 2009.

14 Golder 2006b, 39, 42.

15 Golder 2006b.

16 Golder 2006b, 80-1.

17 Colomer and Negretto 2005, 68.

18 O'Donnell 1994; Samuels and Shugart 2010.

19 Aleman and Tsebelis 2011; Cheibub 2007.

20 Samuels and Shugart 2010, 16. 
The interesting theoretical question therefore is not why presidential candidates seek coalition partners, but rather why political parties join pre-electoral coalitions to support presidential candidates from parties other than their own. This question poses a puzzle for any explanation of presidential pre-electoral coalitions that goes beyond immediate electoral incentives and relies on promises of office benefits or policy influence that parties can realize only after the election. Moreover, if pre-electoral coalitions are not binding past election day, then they should not influence the election outcome either. Ideological proximity or office-seeking motivations would lead to electoral co-ordination or co-operation in government, even absent any preelectoral agreement. In short, whether presidential pre-electoral coalitions matter past election day, or how they matter, is important for understanding why parties form them in the first place.

\section{WHY PRESIDENTIAL ELECTORAL COALITIONS?}

To solve the puzzle of presidential pre-electoral coalitions, I first identify the goals of political parties, or why they seek to control government. I then explain how the act of forming a preelectoral agreement itself can help parties achieve some of these goals, without assuming that parties will be able to hold post-electoral governments accountable to these pre-electoral agreements. In particular, to understand why some parties join presidential electoral coalitions and why others do not, I distinguish parties that seek to maximize their influence on public policy from those that exclusively seek office (and the associated benefits bestowed upon those who gain office). Scholars have drawn distinctions between policy-seeking and office-seeking parties in deriving theoretical expectations of coalition behavior for as long as they have been studying coalitions. ${ }^{21}$ At the same time, scholars often argue that in reality most parties seek both policy and office benefits. ${ }^{22}$ This may be true of programmatically oriented parties, in that they have policy goals but would also like to share in the distribution of office benefits, either for their intrinsic value or for their instrumental value in terms of policy influence. In other words, a programmatic, policy-seeking party may also have particularistic goals and seek office-based rewards.

Yet the purely office-seeking party is not simply a useful theoretical abstraction. In some countries, some political parties are actually devoid of any coherent programmatic or policy orientation. Different from centrist, catchall parties, these political parties seek instead narrowly targeted pork or other particularistic benefits for a specific group or region. They represent voters who want jobs and benefits delivered to their neighborhoods or villages; ideological platforms will not win their votes. They compete for places in the presidential cabinet because these parties need to get into office in order to access the patronage and other government resources that their constituents demand. ${ }^{23}$ Where non-programmatic office-seeking parties exist, we must take this orientation into account in developing models of presidential coalition formation. ${ }^{24}$ In Africa, policy-seeking parties are thought to be rare and office-oriented (patronage-based) coalition behavior common. ${ }^{25}$ In most of Latin America's multiparty systems, albeit to varying degrees, we find that particularistic-oriented parties compete and win seats alongside other parties that advocate broad policy reform and cultivate programmatic reputations. ${ }^{26}$

${ }^{21}$ Axelrod 1970; Riker 1962.

22 Strøm 1990.

${ }^{23}$ Kitschelt 2000; Kitschelt and Wilkinson 2007.

${ }^{24}$ Kellam 2015.

25 Arriola 2009; van de Walle 2003.

${ }^{26}$ Calvo and Murillo 2004; Desposato 2006; Kellam 2015; Kitschelt et al. 2010; Lyne 2008; Mainwaring 1999; Taylor-Robinson 2010. 
This empirical variation in party orientations allows us to test implications about the causal mechanisms, or motivations, behind pre-electoral coalition behavior that would otherwise be indistinguishable if we only examined cases in which all parties care about both office and policy, or at least must act as if they do.

\section{Office Benefits}

By forming a coalition before the presidential election to support another party's candidate, a party must necessarily give up its own candidate's nomination. For personalist parties that are no more than an electoral vehicle for their leader, this is likely to be cost prohibitive. But officeoriented parties do not always, or only, seek the office of the presidency or even other government portfolios. Since presidents in most countries have considerable control over highly valued resources - including patronage, pork appropriations and other government spoils parties can enjoy some types of 'office' benefits simply by being part of the president's support coalition.

Promises to share control of government may be cheap for presidential candidates to make, suggesting that all presidential candidates should offer them in an effort to attract support. But will a newly elected president follow through on promises made to other parties before the election, for example, to give them a specific number of cabinet seats or particular portfolios? The case of the National Rainbow Coalition (NARC) in Kenya serves as a counter-example in which the president did not honor the Memorandum of Understanding (MoU) signed by members of the pre-electoral coalition: 'Only weeks after winning the election in December 2001, the NARC leaders disagreed about the allocation of cabinet portfolios and other important posts, accusing President Mwai Kibaki and his DP/NAK base of keeping the lions share for themselves at the expense of the other coalition partners, contrary to the pre-election agreement. $^{27}$ Will a party honor its agreement four years later to support the presidential candidate from its junior partner? Not necessarily: the Bolivian Movimiento Nacionalista Revolucionario reneged on a rotation clause - signed one year prior to the 1989 presidential election in a secret addendum to the Pacto por la Democracia - that stated the party would support the candidate of their coalition partner, Acción Democrática y Nacionalista. ${ }^{28}$

The situation would be similar in a parliamentary system if a coalition negotiated before the election ended up being larger than necessary to form a government after the election. The empirical record shows that most pre-electoral agreements in parliamentary systems lead to governing coalitions if the election results allow it. ${ }^{29}$ Sona Golder argues that parties must follow through on pre-electoral agreements if they intend to use coalitions in future elections to signal the identity of potential governments to voters. ${ }^{30}$ Also, scholars claim that since political parties are involved in repeated interactions with one another, they may find that they are unable to find coalition partners in the future if they renege on pre-electoral agreements. ${ }^{31}$

Political parties cannot rely on repeated interactions and interbranch or intraparty accountability mechanisms to ensure that pre-electoral agreements regarding the distribution of office benefits are upheld in presidential systems. Presidents, not their parties, have full discretion over the cabinet. Since office-seeking parties want to be in the governing coalition, it is difficult for them to punish presidents who give less than promised. It may be costly for a

27 Kadima and Owuor 2006, 196; Tsuda 2010; Wahman 2011b.

28 Gamarra and Malloy 1995, 414-16.

29 Debus 2009; Golder 2006b; Martin and Stevenson 2001.

30 Golder 2006b.

31 Carroll and Cox 2007; Golder 2006b; Goodin, Guth and Sausgruber 2008. 
party to honestly and publicly report when their private negotiations with the president made before the election are not subsequently honored. Pulling out of the presidential coalition in protest would be extremely costly for an office-oriented party that depends on resources under the president's control. From presidents' perspectives, office-seeking parties can be cheap governing partners - in policy terms - if they want to avoid making the policy concessions demanded by other political parties. Where non-programmatic political parties negotiate their support in exchange for office benefits, jockeying among parties may allow presidents to govern with shifting coalitions as they move through their legislative agendas. ${ }^{32}$ Presidents have the upper hand in post-electoral coalition bargaining, knowing that office-oriented parties will struggle to survive through the next electoral cycle if they do not have access to the resources necessary to meet their constituents' particularistic demands. This means that other political parties, and voters, cannot be fully informed as to whether any of the presidential contenders (or their co-partisans) in the current election had ever reneged in the past.

Since parties cannot reliably punish presidents or presidential parties who fail to honor their pre-electoral agreements, political parties cannot use pre-electoral coalitions in support of another party's candidate as an office-seeking strategy. Rather, because of electoral uncertainty, office-oriented parties may perceive high costs: if they were to form a coalition with a candidate who loses, they may worry that it could reduce the probability that they will get into government. Under most circumstances, office-oriented political parties will prefer to wait until after the election to bargain with the president by offering their legislative support in exchange for cabinet posts and other government resources. Continuing with the example from above, a member of the Kenyan NARC subsequently stated that his party 'will only enter into any MoU with another party or parties after elections [...] We have learnt our political lessons'. ${ }^{33}$

In short, the coalitional behavior of office-oriented parties will differ in the pre- and postelectoral periods. Even though office-oriented parties are unconstrained by ideological or policy considerations, they are unlikely to hire out their support in presidential elections. By forming a coalition ahead of the election to support another party's candidate, a party must necessarily give up its own candidate's nomination. While the VP nomination may appease some parties, it is not always on the table and is also limited. More generally, parties cannot reliably influence the distribution of other offices and resources in the government that forms after the election in a way that would increase their expected benefits. Apart from an immediate electoral advantage in concurrent legislative elections that may come from participating in a coalition, office-oriented political parties have little incentive to join pre-electoral coalitions in presidential elections, even when they do not field their own candidate.

\section{Policy Influence}

While some parties may be exclusively office oriented, others have policy goals. Parties running presidential candidates sometimes offer policy concessions to attract electoral coalition partners. Policy incentives to form a coalition ahead of the presidential election can be similar to the incentives in parliamentary systems, where parties form pre-electoral coalitions because they potentially influence the policy priorities of the government that forms after the election. ${ }^{34}$ We expect parties to form pre-electoral coalitions with candidates from other parties that are closer to them in terms of policy preferences or ideology. Even if their favored presidential

32 Kellam 2015.

33 This quote (emphasis added) is attributed to Environment Minster Kalonzo Musyoka of the Liberal Democratic Party in The Nation on 20 September 2004, as cited by Kadima and Owuor (2006, 197).

${ }^{34}$ Bandyopadhyay, Chatterjee, and Sjöström 2011; Debus 2009; Golder 2006b. 
candidate is able to win office without forming a pre-electoral coalition ahead of the first round, campaigning separately requires that parties distinguish themselves from others, which may make it more difficult to arrive at the same policy compromise after the election. Yet a party that does not distinguish itself from others runs the risk of blurring its platform and being perceived as a sell-out lacking in ideological principles. ${ }^{35}$ In other words, forming pre-electoral coalitions may potentially dilute parties' policy reputations. The relative policy positions of the potential opposition may influence party leaders' considerations in this regard, such that pre-electoral coalitions will be more common in more ideologically polarized political systems. ${ }^{36}$

While promises to share office benefits may be cheap to make since they are usually made behind closed doors, when parties running presidential candidates make policy compromises to other parties as part of the public campaign, they incur some cost. It is costly for presidential candidates to offer policy concessions as part of coalition agreements made before the election, because even if he or she does not win the election, their party dilutes its policy reputation by campaigning on a compromise platform that it otherwise would not have adopted, or by abandoning other positions that they otherwise would have emphasized. For the 1992 presidential elections in Ecuador, for instance, the political director of the Partido Unión Republicana worried that his party's alliance with the Partido Conservador Ecuatoriano 'would lessen Durán Ballén's ability to market himself as an independent candidate at the center of the political spectrum'. ${ }^{37}$ These compromises also make the presidential party more vulnerable to challenges from other parties that may move in to fill their previous ideological niche; similar challenges may arise from factions within the presidential party. A candidate who moves toward the center, for example, may lose the support of a more extreme faction within his or her own party that breaks off to support an alternative candidate or simply does not turn out to vote. The Brazilian Partido dos Trabalhadores has lost leftist factions and left-leaning coalition partners as it has formed more centrist electoral alliances and made pragmatic VP nominations of candidates from other parties.

Because they affect the party's platform or ideological reputation, and future electoral success, political parties (and candidates) will only selectively form pre-electoral agreements that entail such policy compromises. Candidates and their parties are unlikely to form preelectoral agreements with parties from the opposite end of the policy spectrum, and more ideologically rigid parties will be less inclined to form them in general. Consequently, preelectoral agreements convey information to other parties about the policy positions of presidential candidates. By getting the candidate to publicly commit to a policy compromise ahead of the election, parties reduce uncertainty over the future policy-making process.

However, we know that presidential candidates sometimes violate their campaign platform, or mandate, once in office. ${ }^{38}$ They may dissimulate on the campaign trail, or they may change their policy preferences once in office in response to new information or new circumstances. ${ }^{39}$ David Samuels and Matthew Shugart claim that mandate representation is less likely when a separately elected president has significant control over the policy process, or the distribution of the spoils of office, because the president may engage in 'policy switching' and his or her legislative copartisans cannot remove him or her from office. ${ }^{40}$ Only presidential systems that encourage the 'generation of congressional majorities elected on the same national issues as the

${ }^{35}$ Martin and Vanberg 2008

36 Golder 2006b.

37 Conaghan 1995.

38 O’Donnell 1994; Samuels and Shugart 2010; Stokes 2001.

39 Stokes 2001.

40 Samuels and Shugart 2003. 
president $[\ldots]$ have the potential to generate something approximating mandate representation, whereby the campaign produces a president with a mandate based on programmatic commitments articulated in the campaign and a congress that is likely to share the same mandate'. ${ }^{41}$ These authors emphasize potential because presidents could still break their commitments and keep their jobs. Even though the party cannot hold the president accountable in the parliamentary sense (by firing him or her), the legislative contingent could refuse to support the policy switch if they think it sufficiently electorally damaging. Presuming that the legislature plays a role in policy making, this may be an important constraint on a president who would have liked to switch policies. ${ }^{42}$

Scholars argue that policy switches are more likely when the president's party lacks a majority. Since minority presidents can forge coalitions without the consent of their own party, Samuels and Shugart argue that presidents are least constrained when their parties lack a majority. ${ }^{43}$ In these cases, presidents may see their prior policy commitments as subject to renegotiation because either post-election coalition partners or an opposition majority 'may insist on deviations from the governing party's campaign platform' ${ }^{44}$ Pre-electoral coalitions may change the conditions for mandate representation when the president's own party lacks a legislative majority. A policy agreement between parties that is part of a joint campaign platform may encourage 'unity of purpose' between a minority president and a congressional majority made up of multiple parties if they expect to face a common electoral fate. ${ }^{45}$ A political party that expects voters will hold it accountable to a shared mandate or policy program articulated during the campaign will withdraw from the president's legislative coalition if he or she attempts a policy switch. For example, Ecuadorian President Lucio Gutiérrez's economic policies and negotiations with the International Monetary Fund contradicted the anti-neoliberal platform of the Partido Sociedad Patriótica and the Movimiento Unidad Plurinacional Pachakutik (MUPP) electoral alliance; Gutiérrez gained the support of the rightist Partido Social Cristiano in Congress, but subsequently lost the support of his coalition partners, including the MUPP. ${ }^{46}$ Where the opposing coalition or set of parties that did not participate in the pre-electoral coalition provide insufficient support for the president, the coalition partner's threat to pull out may rein in some presidents' temptations to change the policy direction of their government. Also, presidents who seek re-election know that if they stray too far from the policy compromise worked out with their coalition partners ahead of the last election, then their partners will be unwilling to support them in the subsequent election because they will have to protect their own policy reputations. In other words, pre-electoral coalitions influence policy outcomes in the same way as post-electoral coalitions do in presidential systems, but in doing so, pre-electoral coalitions provide a link between campaign platforms and the ultimate policy outcomes.

Thus, the question of accountability underlies pre-electoral coalition behavior in presidential systems. Even though pre-electoral coalitions do not bind presidents to the policy compromises worked out before elections, the act of forming such coalitions helps policy-oriented political parties identify and elect presidential candidates who are most likely to pursue policies that these parties (and their supporters in the electorate) favor. It is in this way that pre-electoral coalitions in presidential systems matter beyond election day. Post-electoral coalitions allow

${ }^{41}$ Samuels and Shugart 2003, 52, emphasis in original.

42 Johnson and Crisp 2003.

${ }^{43}$ Samuels and Shugart 2010, 227.

${ }^{44}$ Stokes 2001, 65.

${ }^{45}$ Samuels and Shugart 2003.

${ }^{46}$ Latin American Weekly Report, 20 April 2004. 
presidents to move away from the policy platform supported by their pre-electoral coalitions only if alternative legislative majorities find these switches favorable. If presidents renege on pre-electoral policy agreements, policy-oriented parties can always withdraw their support and protect their own policy reputations from suffering further dilution - unlike office-oriented parties, as discussed earlier.

To summarize, once we identify parties' incentives to form a pre-electoral coalition to support another party's presidential candidate, we find that pre-electoral coalition behavior will differ according to parties' goals as follows: in pursuit of policy goals, political parties are likely to form electoral coalitions to support presidential candidates from other parties as the ideological distance between the parties decreases; yet presidential electoral coalitions are less likely to include exclusively office-oriented parties that do not promote a programmatic agenda of their own.

\section{EMPIRICAL EVALUATION}

The theoretical argument presented above to explain why parties form pre-electoral coalitions in presidential elections implies the following testable hypotheses:

HYPOTHESIS 1: All else equal, policy-seeking political parties are more likely than officeseeking parties to join pre-electoral coalitions to support presidential candidates from other parties.

HYPOTHESIS 2: All else equal, policy-seeking political parties are less likely to join pre-electoral coalitions to support presidential candidates from other parties as their ideological distance from the candidates' parties increases.

Since the pre-electoral coalition behavior of office-seeking parties should not depend on the position of the presidential candidate's party, the ideological distance variable must be interacted with the party orientation variable to appropriately test Hypothesis 2 .

Another implication of the argument with regards to presidential accountability is that policyseeking parties may be more likely to support a presidential candidate from another party who has at least the possibility of running for immediate re-election if they think they can use the threat of losing their future support to keep the president accountable to pre-electoral policy agreements. They should be less likey to join pre-electoral coalitions supporting incumbent presidential candidates seeking their final terms in office or any candidate running in a system that prohibits immediate re-election.

HYPOTHESIS 3: All else equal, policy-seeking parties are more likely to join pre-electoral coalitions to support other parties' presidential candidates who could potentially run for immediate re-election than they are to join those in support of candidates prohibited from seeking a subsequent term.

Again, since Hypothesis 3 applies to one party type but not the other, testing it also requires an interaction term.

According to Hypothesis 3, the effect of immediate re-election on pre-electoral coalition formation will be in the opposite direction from that suggested by Sona Golder. ${ }^{47}$ She argued that term limits make a party's promise to step aside in favor of their coalition partner's candidate in the next election more credible and increase the divisibility of the presidential office over time. ${ }^{48}$

47 Golder 2006b.

${ }^{48}$ Golder 2006b, 80-1. 
If Golder's argument holds, parties should be less likely to join coalitions to support candidates from other parties where immediate re-election is possible.

Because my theoretical argument implies that a pre-electoral coalition is more likely to form between the party of a presidential candidate and another party if that other party is oriented toward policy goals, rather than office benefits, the primary explanatory variable of interest is the classification of political parties into two types: policy seeking and office seeking. For policy-oriented political parties, I further expect that pre-electoral coalition formation will depend on the extent of programmatic or ideological compatibility with the potential partner. To classify political parties into types, and then identify the ideological or programmatic positions of parties, I rely mostly on Michael Coppedge's classification scheme. ${ }^{49}$ Country experts classify parties along the main, macro-economic policy dimension. Experts place parties that cannot be classified in left-right terms into residual categories. Coppedge's guidelines specifically state that, "parties that are classifiable in left-right terms do not meet the criteria for the "Personalist" or "Other Bloc" categories'; he intends for experts to resort to these residual categories only in 'relatively rare' instances, since most parties are roughly classifiable in left-right terms even if personalism, populism or clientelism make their ideological purity questionable. I code parties placed in the residual categories as having a particularistic orientation, while I code those classified in left-right terms as programmatic. I discuss the classification more thoroughly in the online appendix.

I use this classification of programmatic versus particularistic parties to test hypotheses about how party goals affect electoral coalition behavior by assuming that programmatic parties are Policy Seeking in their effort to advance their programmatic agenda and reputation, and that particularistic parties are Office Seeking because they need to get into office to access the resources necessary to meet their constituents' particularistic demands. For most parties for which experts cannot identify a left-right policy position, it is reasonable to assume that they exclusively seek office and/or access to the pork and patronage that come with it. Yet it is possible that some parties seek to advance a program, principle or ideology that is not classifiable in macroeconomic left-right terms. Ethnic parties, in particular, may be thought of as particularistic in that they seek policies - such as the use of indigenous languages in their local schools - that are highly salient to a particular group but not to others. However, since it may not be reasonable to assume that ethnic parties are exclusively office seeking, I recode ethnic parties as policy seeking, and include an Ethnic Party dummy variable.

I calculate the Ideological Distance between the political party of the presidential candidate and the potential partner as the squared distance between them, using Coppedge's scoring, where parties classified as Left are scored as a -1 , Center-Left as -0.5 , Center as 0 , CenterRight as 0.5 and Right as 1 . For particularistic political parties, which by definition have no ideological position themselves, the Ideological Distance variable simply measures the squared distance of their potential coalition partner from the theoretical center of 0 . I also interact Ideological Distance with the dummy variable indicating the party type (Policy Seeking or Office Seeking) of the potential partner party.

Grigore Pop-Eleches' updates to Coppdedge's data provide classifications for political parties that existed prior to 2003. For more recent parties, I classified them following Coppedge's coding rules. In the online appendix, I consider an alternative coding and use Baker and Greene's data on parties' left-right positions along a 1-20 scale to calculate an alternative measure of distance between potential coalition partners. ${ }^{50}$

49 Coppedge 1997.

50 Baker and Greene 2011; Pop-Eleches 2009. 
TABLE 1 Independent Variables and Expected Relationships

\begin{tabular}{|c|c|c|}
\hline Variable & Operationalization & Sign \\
\hline Policy-Seeking Party & $\begin{array}{l}1 \text { if } P_{B} \text { is a policy-seeking party, } 0 \text { if } P_{B} \text { is an } \\
\text { office-seeking party }\end{array}$ & + \\
\hline Squared Distance & $\left(\text { Position }_{P_{B}}-\text { Position }_{P_{A}}\right)^{2}$ & 0 \\
\hline Policy-Seeking Party $\times$ Distance & & - \\
\hline Immediate Re-election & $\begin{array}{l}1 \text { if allowed and the presidential candidate is not } \\
\text { running for final term, } 0 \text { otherwise }\end{array}$ & 0 \\
\hline Policy-Seeking Party $\times$ Re-election & & + \\
\hline Ethnic Party & 1 if $P_{B}$ is classified as an ethnic party, 0 otherwise & - \\
\hline Run-off System & $\begin{array}{l}1 \text { if majority run-off or reduced threshold run-off } \\
\text { system used to elect president, } 0 \text { if plurality rule } \\
\text { or electoral college used }\end{array}$ & - \\
\hline Concurrent Election & $\begin{array}{l}1 \text { if presidential and legislative elections held on } \\
\text { same day, } 0 \text { otherwise }\end{array}$ & - \\
\hline Lagged Effective Number of Parties & Calculated based on seat shares in lower house & + \\
\hline Lagged Legislative Polarization & $\begin{array}{l}\text { Left-right dispersion away from the relative center } \\
\text { of the legislature, weighted by seats, scaled } 0-1^{\dagger}\end{array}$ & + \\
\hline Laooed Seat Ratio & SeatShare $_{P_{B}}$ & + \\
\hline Laggea seat Nallo & $\overline{\text { SeatShare }_{P_{A}}+\text { SeatShare }_{P_{B}}}$ & \\
\hline
\end{tabular}

Note: $P_{A}$ is the presidential candidate's party and $P_{B}$ is the potential partner party. Lagged measures are based on previous legislative elections for concurrent systems, and the most recent legislative election for non-concurrent systems.

${ }^{\dagger}$ Coppedge 1998.

As emphasized in previous research, further testable hypotheses are implied by expectations of strategic voting and elites' strategic co-ordination in response. Thus I also include variables indicating the type of presidential electoral system, whether legislative elections were held concurrently with the presidential election, the size of the party system, the extent of ideological polarization in the previous legislature and the relative size of the potential partner party based on previous seat shares. In Table 1, I present a summary of theoretical expectations and operationalizations for the variables that I include in my empirical model of presidential preelectoral coalition formation. I refer to the presidential candidate's party as $P_{A}$ and the potential partner party as $P_{B}$.

\section{Data on Presidential Electoral Coalitions in Latin America}

To evaluate the empirical implications of my argument, I examine electoral coalition patterns across seventy-seven presidential elections held in eleven Latin American countries in the current democratic period, as listed in Table 2. I have compiled coalition data for the first (or only) round of the presidential elections. I include all parties that won at least 1 per cent of seats or 1 per cent of the presidential vote in any preceding election covered in my dataset. I exclude presidential candidates who ran as independents. ${ }^{51}$

Presidential candidates can form a pre-electoral coalition with more than one party: while the majority of the pre-electoral coalitions I identified involved an alliance of just two parties, the maximum number of parties in a single candidate's pre-electoral coalition across all cases

${ }^{51}$ Independents or 'others' are reported in eleven elections, with an average vote share of 4.3 per cent. 
TABLE 2 Frequency of Electoral Coalitions among Major Presidential Candidates

\begin{tabular}{lccr}
\hline \hline & \multicolumn{2}{c}{ Candidates with vote $>10 \%$} \\
\cline { 2 - 4 } & Formed coalition & Total & $\%$ \\
\hline Argentina (1983-2007) & 14 & 17 & 59 \\
Bolivia (1985-2009) & 6 & 24 & 25 \\
Brazil (1989-2006) & 10 & 15 & 67 \\
Chile (1989-2009) & 9 & 12 & 75 \\
Colombia (1978-2006) & 1 & 21 & 5 \\
Costa Rica (1953-2006) & 5 & 32 & 16 \\
Ecuador (1978-2009) & 12 & 36 & 33 \\
Mexico (2000-2006) & 4 & 6 & 67 \\
Peru (1980-1990, 2001-2006) & 3 & 14 & 21 \\
Uruguay (1984-2009) & 2 & 18 & 11 \\
Venezuela (1963-2006) & 12 & 26 & 46 \\
Total & 78 & 221 & 35 \\
\hline \hline
\end{tabular}

is seven. However, each party that does not contest the race itself can support only one presidential candidate. I organize the coalition data in dyadic form by pairing each presidential party (a party that ran a presidential candidate) with every other included party, as described above. My dependent variable indicates whether each party-dyad formed a pre-electoral coalition (1) or not (0).

Empirical identification of electoral coalitions is challenging. ${ }^{52}$ While it is straightforward to identify a pair of parties that has not formed a presidential electoral coalition (because they both run candidates or both do not), it is harder to know the level of co-operation when one party runs and the other does not. Candidates' coalitions, and the constituent parties, are sometimes listed in official election returns, but not always. For example, Chilean political parties in coalitions make official statements declaring the candidate of another party as their presidential nominee, but only the presidential candidate's own name appears on the presidential ballot and in official election results, without any indication of partisan affiliation or coalition membership. In contrast, Mexican coalition candidates for president appear on the ballot listed by the name of the coalition, with the symbols of the constituent parties showing as well, and official returns attribute the votes to the coalition. In Argentina and Venezuela, votes for a single presidential candidate are sometimes cast for multiple parties endorsing that candidate, with official election results broken down by party and the total votes for the candidate pooled across all of the parties in the coalition. Although electoral co-operation of one party with another may take several forms in practice, in compiling the data I have counted as pre-electoral coalitions when (1) one party officially nominates the presidential candidate from another party as its own candidate or (2) two or more parties officially contest the presidential election as a coalition. (See the online appendix for the sources consulted.)

Using both criteria as evidence of a pre-electoral coalition, my data indicate that thirty-four (44 per cent) of the seventy-seven candidates who ultimately served as president ran under a pre-electoral coalition in the first (or only) round. More generally, a pre-electoral coalition supported more than one-third of the 221 candidates who won more than 10 per cent of the vote (and about one-quarter of all candidates who competed) in seventy-seven presidential elections

${ }^{52}$ Golder 2006b; Mainwaring and Shugart 1997. 


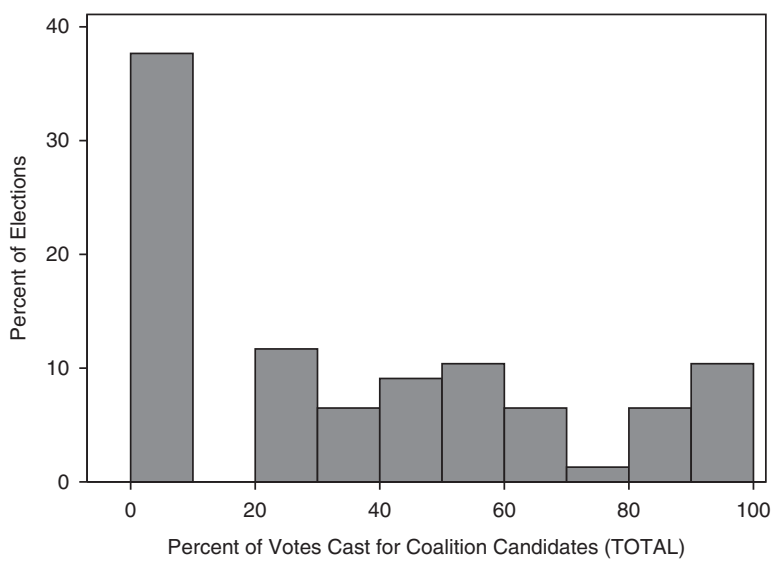

Fig. 1. Coalition candidates' vote share across presidential elections

held across these eleven countries. In short, electoral coalitions are not uncommon in plurality or first-round presidential elections. Table 2 shows that, across countries, the share of major coalition candidates ranged from 5 to 75 per cent. Figure 1 shows that pre-electoral coalition candidates were important in many, but not all, presidential elections in my dataset.

\section{An Empirical Model of Pre-electoral Coalition Formation}

I analyze these presidential pre-electoral coalition data from Latin America in an empirical model that predicts the probability that a particular pair of political parties will form a preelectoral coalition. ${ }^{53}$ I consider several estimation techniques. By employing a rare events logit model, I adjust for the rareness of pre-electoral coalitions in my dataset, given the great number of parties in many of the countries and the dyadic structure of the data. I estimate a conditional fixed-effects logit model to deal with unobserved country-specific heterogeneity, and a randomeffects model that accounts for election-specific heterogeneity. As reported in Table 3, the main findings are robust across estimations. Below, I focus on the final column of results that follows empirical work on pre-electoral coalitions in parliamentary systems by modeling random effects specific to each election. ${ }^{54}$ This estimation accounts for unobserved factors that make pre-electoral coalitions more or less likely in any particular electoral contest. ${ }^{55}$

To examine the substantive effects of the findings, I assess how the predicted probability of presidential electoral coalition formation changes with relevant changes in the explanatory variables.

In calculating changes in the predicted probabilities, I hold all other variables at their medians. Thus the predicted probabilities refer to concurrent elections held under majority run-off rules without the possibility of immediate re-election. Figure 2 illustrates the marginal effects of the interacted variables, which correspond to tests of Hypotheses 1-3. The figure shows the 95 per cent confidence interval for the change in the predicted probability of presidential electoral coalition formation at each value of ideological distance between a presidential candidate's party and a potential partner party. In this figure, ideological distance is

53 The analysis is based on sixty-nine elections due to lagged variables.

54 Golder 2006b.

55 The election-specific variance component is 0.26 ; a likelihood ratio test shows that the random-effects model is preferred to a standard logit model. 


\begin{tabular}{lcccc}
\hline \hline & Logit & $\begin{array}{c}\text { Rare events } \\
\text { logit }\end{array}$ & $\begin{array}{c}\text { Conditional fixed } \\
\text { effects logit }^{b}\end{array}$ & $\begin{array}{c}\text { Random } \\
\text { effects logit }\end{array}$ \\
\hline Policy-Seeking party & $1.179 * * *$ & $1.165 * * *$ & $0.928 * * *$ & $1.057 * * *$ \\
& $(0.375)$ & $(0.375)$ & $(0.331)$ & $(0.333)$ \\
Squared Distance & -0.526 & -0.438 & -0.735 & -0.677 \\
& $(0.496)$ & $(0.495)$ & $(0.555)$ & $(0.565)$ \\
Policy-Seeking Party $\times$ Squared Distance & -0.422 & -0.490 & -0.241 & -0.301 \\
& $(0.569)$ & $(0.568)$ & $(0.577)$ & $(0.587)$ \\
Immediate Re-election Possible & 0.661 & 0.687 & 0.108 & 0.0835 \\
& $(0.570)$ & $(0.569)$ & $(0.478)$ & $(0.542)$ \\
Policy-Seeking Party $\times$ Re-election & -0.420 & -0.437 & -0.255 & -0.420 \\
& $(0.458)$ & $(0.457)$ & $(0.470)$ & $(0.478)$ \\
Ethnic Party & -0.973 & -0.814 & -0.190 & -0.472 \\
& $(0.592)$ & $(0.591)$ & $(0.638)$ & $(0.627)$ \\
Run-off System & $-0.633 * *$ & $-0.635 * *$ & -0.117 & -0.555 \\
Concurrent Elections & $(0.269)$ & $(0.268)$ & $(0.588)$ & $(0.425)$ \\
& -0.192 & -0.203 & 0.103 & 0.141 \\
Lagged ENPS & $(0.355)$ & $(0.355)$ & $(0.281)$ & $(0.497)$ \\
Lagged Legislative Polarization & 0.0436 & 0.0436 & -0.0590 & $0.183 *$ \\
& $(0.0721)$ & $(0.0720)$ & $(0.0565)$ & $(0.0984)$ \\
Lagged Seat Ratio & 0.207 & 0.206 & -0.927 & -0.819 \\
& $(1.094)$ & $(1.092)$ & $(0.955)$ & $(1.313)$ \\
Constant & -0.0407 & -0.0351 & -0.114 & -0.0333 \\
& $(0.304)$ & $(0.304)$ & $(0.229)$ & $(0.235)$ \\
& $-3.783 * * *$ & $-3.742 * * *$ & & $-4.322 * * *$ \\
\hline \hline
\end{tabular}

Note: Observations $=6,414(2.43 \% 1 \mathrm{~s})$, elections $=69$, countries $=11$.

${ }^{a}$ Robust standard errors clustered by election

${ }^{b}$ Country-specific fixed effects

${ }^{c}$ Election-specific random effects.

$* * * \mathrm{p}<0.01, * * \mathrm{p}<0.05, * \mathrm{p}<0.1$

indicated as the absolute value even though the squared value is included in the statistical model. Note that I do not calculate the marginal effect of being a policy-seeking, rather than an office-seeking, party at ideological distances greater than one because one is the maximum value among party dyads that include office-seeking parties.

The top panel of Figure 2 shows that policy-seeking political parties are more likely than office-seeking parties to join pre-electoral coalitions, except at high levels of ideological distance, as implied by my theoretical argument. Given a center-left or center-right president, equivalent to distance of 0.5 , the predicted probability of pre-electoral coalition formation for an exclusively office-seeking party is 0.01 with a 95 per cent confidence interval of $[0.006,0.02]$. For a policy-seeking party with a distance of 0.5 from the presidential candidate's party, the predicted probability would increase to 0.03 [0.02, 0.05]. Given the rarity of pre-electoral coalition formation among all party dyads, these probabilities are small. Yet the difference represents a 157 per cent increase in the predicted probability of forming a pre-electoral coalition.

The middle panel illustrates that for policy-seeking parties, the probability of electoral co-operation depends on the ideological distance between presidential parties and potential coalition partners. Increasing the ideological distance from the presidential party decreases the 


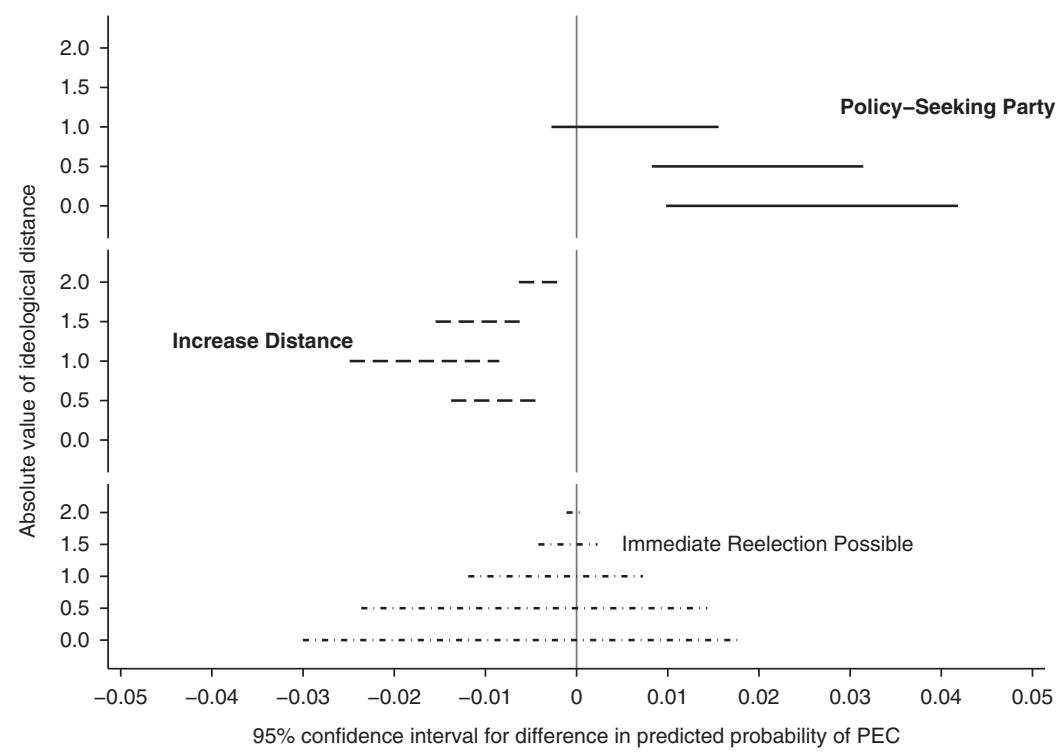

Fig. 2. Marginal effects on the probability of pre-electoral coalition formation

likelihood that a programmatic political party will join an electoral coalition, as would be expected. When ideological distance increases from 0.5 to 1.0 , the change in the predicted probability of pre-electoral coalition formation for a policy-seeking party is $-0.015[-0.025,-0.008]$. This is equivalent to a 51 per cent reduction in the predicted probability. However, the ideological position of the presidential party does not matter when the potential partner is an office-seeking party. Although the marginal effects for office-seeking parties are not included in the figure, note the non-significant coefficient on the non-interacted ideological distance variable in the estimation results.

These findings are consistent with Hypotheses 1 and 2. However, as illustrated in the bottom panel of Figure 2, the analysis does not produce a statistically significant effect for the possibility of presidential re-election on the likelihood of pre-electoral coalition formation (Hypothesis 3).

Some of my additional findings are consistent with previous research. In the logit estimations that do not account for country- or election-specific effects, run-off electoral systems (compared to plurality systems) reduce the predicted probability of pre-electoral coalition formation. The rare events estimation indicates about a 50 per cent difference in the relative risk of pre-electoral coalition formation. Using a different model specification, Jae-Jae Spoon and Karleen West also demonstrate empirically that plurality rules increase electoral co-ordination in the form of preelectoral coalitions to contest presidential elections. ${ }^{56}$ The random-effects estimation indicates that pre-electoral coalitions are more common in systems with more parties, with a positive coefficient on the lagged effective number of parties. Although the estimated lagged seat ratio is not statistically significant in the results reported in Table 3, it is negative and highly significant when I exclude from the analysis party dyads for which the potential partner party did not obtain at least 1 per cent of the seats in the previous legislative election (see the online appendix). These auxiliary results suggest that pre-electoral coalitions are less likely to form the larger the

56 Spoon and West 2015. 
potential partner party is relative to the presidential party, which is similar to Sona Golder's finding regarding asymmetry in the electoral strength among potential coalition parties. ${ }^{57}$

Recall from my discussion above that supporting parties in a pre-electoral coalition are sometimes given the VP nomination. I expect that an offer to nominate one of their own members as the VP candidate may encourage office-seeking parties to join a pre-electoral coalition. I cannot test this hypothesis directly, because the data that I have on VP candidate partisan affiliations only reflects the eventual tickets (that is, the accepted offers) that appeared on the ballot; hence the VP variable perfectly predicts the dependent variable of coalition formation. The findings of my analysis are robust to the exclusion of the twenty-four party dyads in the estimation sample in which a partner party was given the VP nomination (see the online appendix).

Finally, the main findings are also robust to the sequential exclusion of each country from the analysis, as reported in the online appendix. I also report results using a stricter coding of officeseeking parties and the alternative measure of ideological distance mentioned above. When I use this alternative measure, I estimate a statistically significant coefficient on ideological distance, which indicates that the more extreme the position of the presidential candidate's party, the lower the probability of forming a pre-electoral coalition with an office-seeking party. Consequently, this alternative result indicates a smaller, still statistically significant, marginal effect for policy-seeking parties.

\section{CONCLUSION}

This article addresses the question of why a political party would formally support a presidential candidate from another political party. We often read that presidential candidates buy other parties' support with promises to share spoils, distribute specific cabinet portfolios and make certain policy concessions to their legislative agendas should they win office. At the same time, previous work on presidentialism has emphasized the lack of interbranch and intraparty accountability, leading to the claim that electoral coalitions are not binding in presidential systems. This suggests the need for some other theoretical argument to explain why parties form pre-electoral coalitions in presidential elections.

I argue that pre-electoral coalitions help political parties pursue some goals but not others. In particular, by forming a pre-electoral coalition for the presidential election, parties can identify and support presidential candidates who are willing to compromise on policy and, if elected, would be most likely to pursue a policy agenda that they find favorable. Because the policy agreements of pre-electoral coalitions are stated publicly on the campaign trail, they affect parties' and candidates' platforms and ideological reputations. As a consequence of these costs, pre-electoral agreements reveal information about parties and their candidates. Presidents may not follow through on their campaign pledges, but policy-oriented parties can always withdraw from the coalition if they are concerned about violating their own mandates. Thus the patterns of presidential pre-electoral coalition formation highlighted in this article are similar in many ways to patterns of pre-electoral coalitions in parliamentary systems made evident in previous research. In particular, 'Electoral coalitions are less likely to form the more ideologically incompatible the potential coalition members. ${ }^{58}$ By explaining how presidential pre-electoral coalitions can help parties achieve their policy goals even though there are no institutional or other means to compel presidents to uphold their pre-electoral agreements after the election, I offer an important theoretical contribution to the literature on multiparty presidentialism.

${ }^{57}$ Golder 2006c.

${ }^{58}$ Golder 2006c, 203. 
In contrast to policy motivations for forming a presidential pre-electoral coalition, I argue that political parties cannot use pre-electoral agreements to reliably influence their expected share of office benefits in presidential systems. Office-oriented political parties do not have an incentive to punish a presidential candidate who fails to deliver on his or her promises. Knowing this, political parties will wait until after the election has determined a winner to negotiate their share of the spoils. Michael Wahman argues that a similar logic explains oppositional pre-electoral coalition patterns in competitive authoritarian regimes: if there is no policy divide between the opposition and the government, opposition parties are less likely to form pre-electoral coalitions and more likely to 'act opportunistically and delay coalition building until after elections to enable bargaining with the incumbent government as well as other oppositional parties'. 59

The pre-electoral coalition data that I compiled for eleven countries in Latin America indicates that pre-electoral coalitions are not uncommon in multiparty presidential elections, even in the first round, and are important for understanding how presidential aspirants win elections. I pair each party that ran a presidential candidate with every other political party and estimate a model to predict the probability that the dyad will form a pre-electoral coalition. The results of this analysis show that pre-electoral coalition patterns differ between types of parties, policy seeking versus office seeking, in ways that are consistent with my theoretical argument.

This article refines the conventional wisdom about presidential pre-electoral coalitions. The argument and supporting evidence suggest that political parties behave as though presidential pre-electoral coalitions matter past election day. Although such agreements are not binding, presidential pre-electoral coalitions can help parties achieve their policy goals. By publicly committing to a policy compromise ahead of the election, parties reduce uncertainty over the future policy-making process. Thus pre-electoral coalitions potentially affect the outcome of presidential elections, as well as the nature of political representation. This article motivates future research on the relationship between pre- and post-electoral coalitions in presidential systems, and how such coalitions may constrain policy switches and affect democratic representation and governability.

\section{REFERENCES}

Aldrich, John. 1995. Why Parties? The Origin and Transformation of Political Parties in America. Chicago, IL: University of Chicago Press.

Aleman, Eduardo, and George Tsebelis. 2011. Political Parties and Government Coalitions in the Americas. Journal of Politics in Latin America 3 (1):3-28.

Amorim Neto, Octavio, and Gary W. Cox. 1997. Electoral Institutions, Cleavage Structures, and the Number of Parties. American Journal of Political Science 41:149-74.

Arriola, Leonardo R. 2009. Patronage and Political Stability in Africa. Comparative Political Studies 42:1339-362.

Axelrod, Robert. 1970. Conflict of Interest. Chicago, IL: Markham Publishing Company.

Baker, Andy, and Kenneth F. Greene. 2011. The Latin American Lefts Mandate: Free-Market Policies and Issue Voting in New Democracies. World Politics 63:43-77.

Bandyopadhyay, Siddhartha, Kalyan Chatterjee, and Tomas Sjöström. 2011. Pre-electoral Coalitions and Post-election Bargaining. Quarterly Journal of Political Science 6 (1):1-53.

Bawn, Kathleen, and Frances Rosenbluth. 2006. Short Versus Long Coalitions: Electoral Accountability and the Size of the Public Sector. American Journal of Political Science 50 (2):251-65.

${ }^{59}$ Wahman 2011a. 
Blais, Andre, and Indridi H. Indridason. 2007. Making Candidates Count: The Logic of Electoral Alliances in Two Round Legislative Elections. Journal of Politics 69:193-205.

Calvo, Ernesto, and Maria Victoria Murillo. 2004. Who Delivers? Partisan Clients in the Argentine Electoral Market. American Journal of Political Science 48:742-57.

Carey, John M., and Peter M. Siavelis. 2005. Insurance for Good Losers and the Survival of Chile's Concertación. Latin American Politics and Society 47 (2):1-22.

Carroll, Royce, and Gary W. Cox. 2007. The Logic of Gamson's Law: Pre-Election Coalitions and Portfolio Allocations. American Journal of Political Science 51:300-13.

Cheibub, José Antonio. 2007. Presidentialism, Parliamentarism, and Democracy. Cambridge: Cambridge University Press.

Colomer, Josep M., and Gabriel L. Negretto. 2005. Can Presidentialism Work Like Parliamentarism. Government and Opposition 40 (1):60-89.

Conaghan, Catherine M. 1995. Politicians Against Parties: Discord and Disconnection in Ecuador's Party System. In Building Democratic Institutions: Party Systems in Latin America, edited by Scott Mainwaring and Timothy R. Scully, 434-58. Stanford, CA: Stanford University Press.

Coppedge, Michael. 1997. A Classification of Latin American Political Parties, Working Paper No. 244. Notre Dame, IN: Kellogg Institute, University of Notre Dame.

1998. The Dynamic Diversity of Latin American Party Systems. Party Politics 4 (4):547-68.

Cox, Gary, and Mathew McCubbins. 1993. Legislative Leviathan: Party Government in the House. Berkeley: University of California Press.

Debus, Marc. 2009. Pre-Electoral Commitments and Government Formation. Public Choice 138 (1-2): $45-64$.

Desposato, Scott W. 2006. Parties for Rent? Careerism, Ideology, and Party Switching in Brazil's Chamber of Deputies. American Journal of Political Science 50 (1):62-80.

Ferrara, Federico, and Erik S. Herron. 2005. Going It Alone? Strategic Entry Under Mixed Electoral Rules. American Journal of Political Science 49 (1):16-31.

Gamarra, Eduardo, and James M. Malloy. 1995. The Patrimonial Dynamics of Party Politics in Bolivia. In Building Democratic Institutions, edited by Scott Mainwaring and Timothy R. Scully, 399-433. Stanford, CA: Stanford University Press.

Golder, Matt. 2006a. Presidential Coattails and Legislative Fragmentation. American Journal of Political Science 50:34-48.

Golder, Sona Nadenichek. 2006b. The Logic of Pre-Electoral Coalition Formation. Columbus, OH: The Ohio State University.

2006c. Pre-Electoral Coalition Formation in Parliamentary Democracies. British Journal of Political Science 36:193-212.

Goodin, Robert E., Werner Guth, and Rupert Sausgruber. 2008. When to Coalesce: Early Versus Late Coalition Announcements in an Experimental Democracy. British Journal of Political Science 38:181-91.

Hicken, Allen, and Heather Stoll. 2011. Presidents and Parties: How Presidential Elections Shape Coordination in Legislative Elections. Comparative Political Studies 44 (8):854-83.

Johnson, Gregg B., and Brian F. Crisp. 2003. Mandates, Powers, and Policies. American Journal of Political Science 47:128-42.

Jones, Mark P. 1994. Presidential Election Laws and Multipartism in Latin America. Political Research Quarterly 47:41-57.

1999. Electoral Laws and the Effective Number of Candidates in Presidential Elections. Journal of Politics 61:171-84.

Kadima, Denis, and Felix Owuor. 2006. The National Rainbow Coalition: Achievements and Challenges of Building and Sustaining a Broad-Based Political Party Coalition in Kenya. In The Politics of Political Party Coalitions, edited by Denis Kadima, 179-221. Johannesburg: EISA, Konrad-Adenauer-Stiftung.

Kellam, Marisa. 2015. Parties for Hire: How Particularistic Parties Influence Presidents' Governing Strategies. Party Politics 21:511-26. 
Kitschelt, Herbert. 2000. Linkages Between Citizens and Politicians in Democratic Polities. Comparative Political Studies 33:845-79.

Kitschelt, Herbert, Kirk A. Hawkins, Juan Pablo Luna, Guillermo Rosas, and Elizabeth J. Zechmeister. 2010. Latin American Party Systems. New York: Cambridge University Press.

Kitschelt, Herbert, and Steven I. Wilkinson, eds. 2007. Patrons, Clients and Policies: Patterns of Democratic Accountability and Political Competition. Cambridge: Cambridge University Press.

Linz, Juan. 1994. Presidential or Parliamentary: Does It Make a Difference? In The Failure of Presidential Democracy, Volume 1, edited by Juan Linz and Arturo Valenzuela, 3-88. Baltimore, MD: Johns Hopkins University Press.

Lyne, Mona. 2008. The Voter's Dilemma and Democratic Accountability. University Park, PA: Pennsylvania State University Press.

Machado, Aline. 2009. Minimum Winning Electoral Coalitions Under Presidentialism: Reality or Fiction? The Case of Brazil. Latin American Politics and Society 51 (3):87-110.

Mainwaring, Scott. 1993. Presidentialism, Multipartism, and Democracy: The Difficult Combination. Comparative Political Studies 26 (2):198-228.

1999. Rethinking Party Systems in the Third Wave of Democratization: The Case of Brazil. Stanford, CA: Stanford University Press.

Mainwaring, Scott, and Mathew Shugart, eds. 1997. Presidentialism and Democracy in Latin America. Cambridge: Cambridge University Press.

Martin, Lanny W., and Georg Vanberg. 2008. Coalition Government and Political Communication. Political Research Quarterly 61 (3):502-16.

Martin, Lanny W., and Randolph T. Stevenson. 2001. Government Formation in Parliamentary Democracies. American Journal of Political Science 45:33-50.

O’Donnell, Guillermo A. 1994. Delegative Democracy. Journal of Democracy 5:55-69.

Payne, J. Mark, Daniel Zovatto G., and Mercedes Mateo Díaz. 2007. Democracies in Development: Politics and Reform in Latin America. Washington, DC: Inter-American Development Bank.

Perez-Linan, Anibal. 2006. Evaluating Presidential Runoff Elections. Electoral Studies 25:129-46.

Pop-Eleches, Grigore. 2009. From Economic Crisis to Reform: IMF Programs in Latin America and Eastern Europe. Princeton, NJ: Princeton University Press.

Riker, William. 1962. The Theory of Political Coalitions. New Haven, CT: Yale University Press.

Samuels, David J. 2002. Presidentialized Parties: The Separation of Powers and Party Organization and Behavior. Comparative Political Studies 35:461-83.

Samuels, David, and Matthew Shugart. 2003. Presidentialism, Elections and Representation. Journal of Theoretical Politics 15:33-60.

- 2010. Presidents, Parties, and Prime Ministers: How the Separation of Powers Affects Party Organization and Behavior. New York: Cambridge University Press.

Schwartz, Thomas. 1989. Why Parties? Unpublished research memorandum. Los Angeles: University of California.

Shugart, Matthew Soberg, and John M. Carey. 1992. Presidents and Assemblies: Constitutional Design and Electoral Dynamics. Cambridge: Cambridge University Press.

Spoon, Jae-Jae M., and Karleen Jones West. 2015. Alone or Together? How Institutions Affect Party Entry in Presidential Elections in Europe and South America. Party Politics 21 (3):393-403.

Stokes, Susan C. 2001. Mandates and Democracy: Neoliberalism by Surprise in Latin America. New York: Cambridge University Press.

Strøm, Kaare. 1990. Minority Government and Majority Rule. Cambridge: Cambridge University Press.

Taylor-Robinson, Michelle M. 2010. Do the Poor Count? Democratic Institutions and Accountability in a Context of Poverty. University Park: Pennsylvania State University Press.

Tsuda, Miwa. 2010. The Experiences of the National Rainbow Coalition (NARC): Political Parties in Kenya from 1991 to 2007. Discussion Paper No. 222.2010.02, IDE. Tokyo: Institute of Developing Economies. Available from http://hdl.handle.net/2344/871, accessed 22 July 2011.

van de Walle, Nicolas. 2003. Presidentialism and Clientelism in Africa's Emerging Party Systems. Journal of Modern African Studies 41 (2):297-321. 
Wahman, Michael. 2011a. Offices and Policies: Why Do Oppositional Parties Form Pre-Electoral Coalitions in Competitive Authoritarian Regimes? Electoral Studies 30 (4):642-57.

- 2011b. Policy Blind Coalitions: Ethnicity and Political Coalitions in Kenya Under Multipartyism. Paper Prepared for Delivery at the 4th European Conference on Africa Studies, Uppsala, 15-18 June.

West, Karleen Jones, and Jae-Jae Spoon. 2013. Credibility vs. Competition: The Impact of Party Size on Decisions to Enter Presidential Elections in South America and Europe. Comparative Political Studies 46 (4):513-39. 